\title{
12
}

\section{Radical Enlightenment and revolution in late eighteenth-century Ireland}

\section{Ultán Gillen}

On 1 June 1795, Ireland's most popular newspaper, the Northern Star, summed up the era in which its readers lived:

\begin{abstract}
The present is an age of revolution. Every thing is changing, every system is improving, and mankind appear to become more and more virtuous as they become more informed. This is the consequence of knowledge; the effect of intelligence; the result of truth and reason.
\end{abstract}

This was not intended as an objective description of enlightened times, but as a call to arms to the Northern Star's audience among the middle and lower orders to support the revolutionary programme of the Society of United Irishmen. Founded in October 1791, the Society's original programme called for greater but not full independence from Britain, parliamentary reform, and equal rights for all religious denominations in a country where wealth was overwhelmingly and political power entirely in the hands of the adherents of the Anglican Established Church of Ireland, about 10 per cent of the population. ${ }^{2}$ The United Irishmen used the Northern Star and every other available means of propaganda to spread their message. Banned in 1794 due to their support for and connections with the government of revolutionary France, they had by 1795 decided decisively on the path of armed revolution. 
The popularity of their revolutionary message would enable the United Irishmen to build a mass movement dedicated to overthrowing the political, social, and religious order and establishing an independent, democratic, and secular republic. According to their own records, at their peak the United Irishmen had 280,000 sworn members of a secret society preparing for rebellion. Theobald Wolfe Tone (1763-98), a founding member and foremost among the Society's propagandists, successfully negotiated a military alliance with the French Republic in the space of a few months in Paris in 1796, and the Directory determined to mount a major invasion. ${ }^{3}$ Although when it came, the United Irish rebellion of 1798 was far from that originally envisioned and lacked significant French help, it represented 'the most concentrated episode of violence in Irish history'. 4 Usually remembered in Ireland today as part of a centuries-long struggle for independence, the United Irish rebellion can, and should, be interpreted as a conflict between moderate and radical conceptions of the Enlightenment.

It may be useful at this point to clarify how the terms 'moderate' and 'radical' Enlightenment are used in this chapter. These terms are used primarily in regard to the disputed political implications of core principles of the Enlightenment, such as religious toleration, rather than philosophical concepts such as pantheism or one-substance metaphysics. By the late 1700s, the discourse of Enlightenment figured prominently in Ireland to justify concrete political positions about who ought to exercise political power. Enlightened language was used by defenders of the status quo, by those advocating reforms, and by those seeking revolution. The question of Catholic enfranchisement illustrated the fault lines between moderate and radical conceptions of Enlightenment in Ireland. For example, at a Belfast town meeting held to discuss the Catholic question in January 1792, the Presbyterian cleric and Whig reformer, Doctor William Bruce (1757-1841), objected to enfranchising Catholics at this time on the grounds that 
they were not yet suitably enlightened, and cited in his support the fact that the National Assembly of France, 'the most enlightened assembly the world ever saw' had withheld the vote from certain sections of society. His United Irish opponents, however, expressed outrage that such opinions were voiced in 'the present enlightened era', stating that Catholics should be equal citizens. ${ }^{\mathbf{5}}$ As Irish politics polarized in the period that followed, disagreements over the political implications of the Enlightenment crystallized around fundamental divisions over separation from Britain, the confessional nature of the state, the French Revolution, republicanism, and democracy. Adherents to the moderate position lauded Montesquieu and Locke, the British connection, gradual reform, and upheld monarchy and aristocracy, while opposing the French Revolution and democracy. The arguments were settled on the battlefield against the revolutionaries.

\section{Ireland and the Enlightenment}

The idea that events in Ireland in the 1790s represented a clash between political forces inspired by different interpretations of the Enlightenment instead of a continuation of a long struggle for Irish independence or an outburst of continuous sectarian tension (lasting to this day in Northern Ireland) will surprise some. Amongst historians, the notion of an Irish Enlightenment is a relatively recent one. The term 'Irish Enlightenment' is used here to capture the notion of Irish people as conscious participants in the debates of the Enlightenment internationally, rather than as part of the tendency to see national enlightenments and thus to downplay the cohesion of the Enlightenment across borders. Several prominent Enlightenment writers came from Ireland - for example John Toland (1670-1722), Francis Hutcheson (1694-1746), Bishop George Berkeley 
(1685-1753), and Edmund Burke (1729-97) - but, having largely made their names outside the country, they were subsumed within a Scottish or British context, and not regarded as distinctively Irish. Ireland was not considered at the time to be a centre of Enlightened thought, either by Irish people themselves or by people abroad. As will be discussed later, however, by the end of the century, Irish political culture had developed an image of itself as Enlightened on the basis of its form of government.

Although there had been previous discussion of the influence of the Scottish Enlightenment and John Locke on the United Irishmen in particular, David Berman's two articles on Enlightenment and Counter-Enlightenment in Irish philosophy from 1982 represented a major step forward in the study of the Enlightenment in Ireland, making the case that the idea of an Irish Enlightenment ought to be taken seriously. ${ }^{6}$ At the centre of Berman's model lay the idea that Irish Enlightenment thought could be broken down into left-wing and right-wing interpretations of Locke, but he argued that the philosophical development of the Irish Enlightenment came to a halt in the 1750s. In 1990, Simon Davies published an important article demonstrating how the United Irishmen used the Northern Star to spread the principles of the Enlightenment. ${ }^{7}$ With the bicentenary of the events of the 1790 s stimulating a huge upturn in publications on the period, there was greater interest in how the Enlightenment helped shape those events. ${ }^{\mathbf{8}}$ Combined with the publication of the collection Ireland and the French Enlightenment in 1999, the concept of an Irish Enlightenment gained much wider acceptance among academics. For example, the idea is central to Ian McBride's recent general history of eighteenth-century Ireland, The Isle of Slaves, which includes a chapter dedicated to the Enlightenment and its enemies. ${ }^{9}$ However, there remains a certain amount of scepticism in some quarters, though even there the idea of an Irish Enlightenment centred on practical improvement 
as represented by the likes of the Royal Dublin Society (1731) has been largely accepted. 10 Michael Brown's forthcoming The Irish Enlightenment will redefine the field, moving the debate on the Irish Enlightenment onto new and much more solid ground.

I have argued elsewhere that not only was there an Irish Enlightenment, but in fact that by the 1790s Irish political culture defined itself as Enlightened, and not just at an elite level. 11 As one government-sponsored newspaper angrily noted in spring 1792,

Never was there an unhappy Phrase so abused, as, 'we who live in an enlightened age;' it's the cant term in every whiskey shop, and a fellow who has no intellects to receive any benefits from light, uses it with as much sang froid as $\mathrm{Mr}$. Grattan.

The perception of Ireland as the home of an Enlightened political system stemmed from the fact that Ireland had, theoretically at least, a constitution identical to that of Great Britain after 1688. According to the dominant political ideology, centred on Locke's Two Treatises of Government, the constitution of King, Lords, and Commons, combined with religious toleration, and support from central and local government for economic improvement, provided the epitome of Enlightened government. Property was respected and awarded a say in government, while private religious beliefs were respected, even if political rights remained restricted, and the benefits of scientific advancement were being delivered to the people by a patriotic elite dedicated to economic improvement. In this view, Ireland may not have produced much in the way of enlightened philosophy, but it was at the forefront of applying the principles of the Enlightenment for the benefit of society. This concept of Enlightenment to a large extent fits the model put forward by John Robertson. 13 
Many reformers also accepted the fundamentals of this self-image of an enlightened polity, believing that the introduction of relatively minor reforms would perfect the constitution. Areas of contention included the powers of the Irish parliament, especially the reality of British laws restricting Ireland's trade and therefore her political rights and economic development; parliamentary reform (only one-third of seats were open for election, and government patronage dispensed by a British viceroy ensured a near-permanent parliamentary majority at Britain's service); and the extent to which it was safe to extend civil and political rights to Catholics and Dissenters. What was at stake, in the eyes of both the supporters of the status quo and the moderate reformers, was the application of the principles that underpinned the government, rather than those principles themselves. In the era before the French Revolution, such perspectives were overwhelmingly dominant, but there were those who rejected such a limited analysis, both of the concept of Enlightenment and its implications for Irish politics.

\section{Ireland and Radical Enlightenment}

If by the 1790s Irish political culture defined itself in terms shaped by politically moderate interpretations of Enlightenment principles, where did the revolutionaries of the 1790s find their inspiration? The popularity of generations of opposition politicians rooted in the country or Real Whig tradition and the recurring bursts of popular outrage and agitation when it seemed the rights of the Irish parliament were being trampled on by London contributed to the development of a revolutionary tradition. However, the majority of those within the political nation who represented these trends remained locked in an ideology that rejected the idea of religious equality, and thus remained ultimately supportive of the Protestant constitution that formed the 
status quo. The sources of the secularism that came to define the revolutionary position lay elsewhere, and thus any account of the development of Irish revolutionary ideology that describes it as essentially a Commonwealth man outworking of the Lockean underpinnings of the constitution fails to grasp its true nature. We must look elsewhere, and this chapter argues that the political ideas that sprang from the Radical Enlightenment, as mediated through their popularizers such as Thomas Paine (1737-1809) and the practical example of the French Revolution, were an essential source for the creation of the separatist, democratic, secular, egalitarian political programme of Irish revolutionaries in the 1790s.

One of the few Irish-born Enlightenment philosophers who can be counted a major figure was, of course, John Toland, the republican deist. Raised as a Gaelic-speaking Catholic in Donegal, he converted to Anglicanism and attended university in Scotland, where he embraced Presbyterianism before embracing deism. ${ }^{14}$ He plays an important role in the two most important historiographical models of Radical Enlightenment. Margaret C. Jacob described Toland as the 'spokesman' for the Radical Whigs central to the emergence of the Radical Enlightenment. 15 Jonathan I. Israel regards Toland's contribution to the development of the Radical Enlightenment as 'rather substantial', even if his relationship with the writings of Spinoza was far from straightforward. 16 It is tempting to suggest that the controversial writings on religion of Toland - a man who at various stages of his life embodied the three major religious traditions in Ireland- had their roots in his reaction to growing up among the violent sectarian divisions and power struggles of his native land. Tempting, but too simplistic, and the relationship between Toland's country of origin and his writings is a question that need not detain us here. Of more relevance is the fact that his Christianity not Mysterious (1696) provoked a great deal of hostility in Ireland, with the Irish House of Commons ordering it to be burnt in 
September 1697 and seeking to prosecute Toland, who left the country. ${ }^{17}$ Given this reception, the question then becomes whether Toland inspired a tradition of Radical Enlightenment thinkers in Ireland.

The short answer is 'no': no significant tradition of such thinkers emerged in Ireland over the course of the eighteenth century, not even in the clandestine fashion that Israel notes characterised the Radical Enlightenment as a whole until around 1770. 18 Arguments such as those of Toland were not attractive to a small political and social elite defined, and threatened, by its religious differences with the overwhelming majority of the population. For much of the century, most of those opposed to the status quo also defined themselves in denominational terms. Given the importance of religion to Irish society, political power, and personal selfdefinition, the culture was extremely hostile to what were perceived as atheistic or heretical doctrines. However, Seamus Deane has argued that the revolutionaries of the 1790s should be seen as standing within a tradition in which Toland played an important part:

This double emancipation sought by Toland, for Jews and Dissenters, in the aftermath of the English revolution and during a titanic war with France, was meant both to confirm and to widen the Protestant ideology of Liberty which English republicanism burnished to a high gloss to reflect, dimly at times, figures such as Aristotle, Cicero, Machiavelli, Livy, Sallust, Moses, Lycurgus, Cato and Brutus. Tone and the United Irishmen recognized themselves as belonging to that tradition.

Neither Tone himself nor the United Irishmen openly cited Toland, though as Jim Smyth has noted, Tone pretended to be less familiar with famous works of politics and philosophy than he actually was. $^{20}$ If there is no evidence that Toland's writings directly influenced the United 
Irishmen, and if there was no influential tradition of Radical Enlightenment philosophy being produced in Ireland, how was it that a mass movement aimed at revolutionizing the country according to the democratic principles of the Radical Enlightenment emerged in the 1790s?

Major thinkers of all strands of the Enlightenment were read in Ireland, which had a relatively healthy trade in French books (including the Encyclopédie, seditions tracts, and libelles) and in reprints and translations of major works. ${ }^{21}$ In addition to complete volumes, by the 1790s, extracts from Enlightenment works were regularly printed in magazines and newspapers. The number of people who could read grew as print culture spread, stimulated by economic development, and they had relatively easy access to philosophical works. Therefore, the ideas of important figures in the Radical Enlightenment were relatively well-known among the Irish political nation. ${ }^{22}$ However, it was Ireland's political situation in an age of revolution that created the conditions for the development of what would become the revolutionary ideology of the 1790s, when ideas once restricted to the world of high philosophy become the motive forces for the actions of hundreds of thousands. As Irish people grappled with the questions of how their relationship with Britain impacted upon their country's rights, the political arrangements that would give them a genuine say in government, and the religious divisions among them, radicals moved beyond the restrictive bounds of the moderate and Protestant concept of enlightened government that dominated political culture.

The era of the American Revolution saw the first real seeds of a revolutionary rejection of the status quo begin to sprout. Irish people kept a close eye on developments in the colonies, partly because of parallels that could be drawn between Britain's say in governing the two countries, and in restricting their trade, but also because of the impact of the American war at home. While Vincent Morley has shown that claims that Irish radicals adopted American ideas 
are mistaken, he points out that the American example, combined with the stresses caused by the war against the Americans and their European allies France and Spain, did have important consequences for politics in Ireland, including the first significant moves towards a political radicalism that embraced people of all denominations, and a new openness to the idea amongst not just the Protestant political nation, but the Catholic masses. ${ }^{23}$

The most obvious impact of the American war on Irish politics was the achievement of free trade (the right to trade with Britain's colonies) and of the so-called revolution of 1782, when the Irish parliament won formal legislative independence from Britain, i.e. the right to be the only parliament to make law for Ireland, something previously shared with the British parliament. These concessions were extorted from Britain. After much of the army in Ireland was withdrawn to fight in America, an independent Volunteer movement spread rapidly across the country due to the fear of a French invasion. This army, influenced both by practical need and classical republican notions of citizenship, may have grown as large as eighty thousand strong.

The Volunteers were the armed expression of Irish public opinion, and they were in no mood to let the opportunity the war presented to them slip. With the British government hamstrung by the war, the Volunteers and a number of patriot politicians within and without the Irish parliament sought the redress of long-standing grievances surrounding the rights of the Irish parliament. What distinguished this movement was that it attracted support from people who usually supported the government. At a massive Volunteer demonstration on 4 November 1779, for the anniversary of William of Orange's arrival in Ireland, a sign was hung on a cannon warning 'Free Trade or This'. The British government soon gave way. By 1782, fearful of the consequences of further resistance, London acknowledged Ireland's legislative independence. 
The American war had therefore thrown into question some of the fundamentals of Irish politics over the last century. The Navigation and Woollen Acts had caused William Molyneux, a friend of both Locke and Toland, to publish the foundational text of eighteenth-century Irish patriotism, The Case of Ireland's being bound by Acts of Parliament in England, stated (1698), and Westminster's Declaratory Act of 1720 had reinforced the subordination of the Irish parliament. It seemed now that nearly a century of patriot grievances had been solved, and that the relationship between Ireland and Britain would henceforth genuinely and not just rhetorically be one of equal sister kingdoms. To many in Ireland, the full benefits of 1688 were now theirs.

The Catholic question had also been irrevocably changed by the American war. Irish Catholics represented a large source of potential military manpower that was barred legally (though not in practice) from joining the army. During the American war, the Catholic Relief Acts of 1778 and 1782 allowed Irish Catholics to join the army, and also gave them better conditions for holding land. These were the first breaches in the Penal Laws that had been passed in the aftermath of the war between the forces of William and James, which ended in 1691. The Penal Laws had succeeded in depriving Catholics of political power, and had greatly reduced the amount of land owned by Catholics (the formal figure was 5 per cent, though the real figure was higher due to land being held in the name of friendly Protestants). Although the repeal of these laws was motivated by the military needs of the British empire, and carried out at the behest of the London government, it was broadly welcomed among the Protestant political elite, itself a measure of the influence of Enlightened ideas.

However, there were strict limits to how far the majority of the political nation wanted religious toleration to go. The initial Volunteers feared not only French invasion, but also Irish Catholic rebellion, demonstrating a continued belief that Catholics could not be trusted to be 
good citizens. However, other, more liberal, Volunteer units took a different attitude, and middle-class Catholics were permitted to join in some areas, in defiance of laws that banned them from holding arms. This was a potent assertion of their citizenship, and of its acceptance by radical members of the Protestant political nation. In asserting the equality of Catholics, it also displayed adherence to the radical interpretation of a core Enlightenment principle. This remained strictly a minority viewpoint, however. After the war ended, the Volunteers declined rapidly, but reformers maintained their units, hoping to use the Volunteers to leverage modest parliamentary reform. The movement collapsed in disarray, however, in 1784 over whether Catholics should be granted the vote, a graphic illustration of the dominance of moderate Enlightenment even among reformers.

With official political culture and much of the political nation now content that the constitution had been perfected, Irish adherents of a moderate conception of Enlightenment were triumphant, and they looked to the future with confidence, believing that an age of unparalleled prosperity lay ahead now that Ireland had secured free trade and greater self-government. However, some among the adherents of a radical interpretation of Enlightenment had reached very different conclusions.

William Drennan's (1754-1820) Letters of Orellana, an Irish Helot were first published in the Belfast Newsletter in 1784 . They were a response to the failures of the reform campaign, and an attempt to mobilize opinion in those parts of Ulster that had not enthusiastically supported reform. The Letters were subsequently printed in pamphlet form, including in an edition by the Constitution Society of Dublin to be distributed free in order to spread such knowledge as would cause 'ALL' the people of Ireland 'to think, and act as free-born men'. They hoped thus to increase support for parliamentary reform, and also to combat the efforts of 'traitors' to sow 
division among a people so recently united. The source of all Ireland's calamities, they asserted, was 'the hydra, aristocracy', against which they would wield the freedom of the press to assert their liberty and inform the people. ${ }^{24}$ The publication of the pamphlet was therefore rooted clearly in politics of the Radical Enlightenment - equality for all, meaning all religious denominations and all classes, confidence in the transformative power of knowledge and a free press, and an assault on the power of aristocracy and its ill-effects on the people.

In the Letters themselves, Drennan, who with Wolfe Tone would later be one of the main ideologues of the United Irishmen in their early years, mocked the very idea that under their constitution Irishmen were free. Beginning each letter with the address, 'Fellow slaves!', instantly challenged the claims of civil and political liberty on which the dominant political culture and dominant interpretation of Enlightenment rested. The Volunteers were the heroes of 1782 and held an exalted place in political rhetoric: Drennan dismissed their efforts as ultimately hollow and insufficient for Irishmen to legitimately claim the titles of patriots or freemen. Without their will being properly represented in the legislative process, the people were slaves, a condition worsened by the fact that Ireland's government was in reality still controlled by Englishmen. The failure to critique the connection between Church and State, to apply free thought to the 'sanctified veil of mystery' thrown over religious and civil authority, enfettered the people. ${ }^{25}$ Drennan was speaking the language of the Radical Enlightenment, although as the son of a dissenting minister, he was also giving voice to Presbyterian contempt for the Anglican confessional state.

The people, Drennan said, were, in short, slaves because 'the democratic spirit of the constitution is no more'. 26 The only legitimate source of government and of law were 'those rights respecting life, liberty, and property, without which we cannot be free'. These rights could 
not be guaranteed by a balanced constitution, which must always be illusionary: 'The only solid piles on which the fabric of freedom remains unshaken are constitutional rights, enforced by the controuling energy and momentum of that mighty mass to which those rights belong'.

Constitutional rights were, simply put, 'the rights of human nature'. When one of these rights was violated, the rest were in mortal danger. The American Declaration of Independence, he argued, had been written in accordance with constitutional rights, and this explained why the answer to the question 'what is the distance between an Irishman and a Freeman?' was 'not less than three thousand miles'. ${ }^{27}$ The rejection of the existing constitution was clear. Drennan rejected the claims of longevity and authority used to buttress the constitution, measuring it instead against the doctrine of natural rights and finding it entirely wanting. In effect, what he was calling for was the overturning of the political and religious establishment - a revolution in government and society - even if the means he was calling for (a bigger Volunteer convention) were peaceful rather than violent. Without saying it openly, he endorsed a republic with a democratic form of government, such as existed in the United States, as his preferred form of government. It is unlikely this escaped the attention of those who chose to distribute his pamphlet for free among the Dublin lower orders.

According to Israel, by 1789 the Radical Enlightenment had produced a 'clearly formulated package of basic human rights' composed of 'equality, democracy, freedom of the individual, freedom of thought and expression, and a comprehensive religious toleration'. ${ }^{28}$ If we read the introduction with the Letters, we see that by the mid-1780s, such a package had been embraced by a relatively small number of radical reformers in Ireland, who sought to spread that message to the lower orders. Drennan, who studied at both Glasgow and Edinburgh, was extremely well-educated and familiar with many of the major works of the Enlightenment. The 
Letters, which space has not allowed a full discussion of, reveal the influence of natural rights, Locke and contract theory, Irish patriotism, the American Revolution, and classical republicanism, as well as the political ideas associated with the Radical Enlightenment. Drennan read some of the authors associated by Israel with the Radical Enlightenment. ${ }^{29}$ The political ideas found among the most radical authors of the Enlightenment are reflected in these Letters and a number of other writings from this period. ${ }^{30}$ The Dublin lower orders who were the target audience of the Constitution Society edition were being propagated with the most radical ideas of the day without knowing their ultimate sources. For radicals like Drennan, the incentive to move beyond the politics of the moderate Enlightenment lay in the fact that it had proven insufficient to break the grasp of either Britain on Ireland or of the aristocracy and Established Church on politics and society in Ireland. At this point, such a radical message fell on stony ground, but that changed after 1789 .

\section{The 1790s: Radical Enlightenment and revolutionary Ireland}

In August 1796, by then an officer in the army of the French Republic waiting to invade Ireland, Wolfe Tone sat down to pen his autobiography. He reflected on how a revolutionary situation had emerged in his native land:

In a little time, the French revolution became the test of every man's political creed, and the nation was fairly divided into two great parties, the Aristocrats and the Democrats (epithets borrowed from France), who have ever since been measuring each other's strength and carrying on a kind of smothered war, which the course of events, it is highly probable may soon call into energy and action. ${ }^{31}$ 
Historians agree that it was Irish reactions to the French Revolution and to the war that followed that created the revolutionary conditions in Ireland in the 1790s. Deep-seated tensions surrounding the British connection, the confessional state, sectarianism, and social and economic conditions were exacerbated by the strains put on the status quo by radicals inspired by the French Revolution and by the demands of the war effort. The ideas and example of the French Revolution did not create the conditions for discontent, but they did allow for the emergence of a new political programme capable of attracting wide support across the religious spectrum among the lower and middle orders, and therefore posing a serious challenge to the existing political, social, and religious order. As noted earlier, the seeds of this ideology were already in place, but it was the radically altered world and the sense of open-ended possibility produced by the French Revolution that allowed it to take root among the Irish masses.

The French Revolution was welcomed by Irish radicals as establishing a truly Enlightened government. It seemed to have inaugurated a new phase in human history, a phase where the oppressions and errors of the past could be left behind. To take one example from many, a radical newspaper popular among the Dublin lower orders, the Morning Post, described the new government as 'formed on the great base of reason ... the enlightened system of an enlightened empire; the empire of common sense and equal freedom. Let Irishmen mark the essentials of both, ${ }^{32}$ As the Revolution progressed through its stages towards a democratic republic, it became only more enlightened in the eyes of Irish revolutionaries, especially once the 'sons of liberty' led by the 'illustrious and enlightened Convention of France' were besting the 'tyrants' on the battlefield, raising the possibility of the liberation of all Europe. 33

Having concluded that the Enlightened principles of the French Revolution offered the means to reform Ireland's government, to end the sectarian divisions among her people, and to 
lift the population out of poverty, those seeking revolutionary change needed a strategy. It was clear that using the existing unreformed political institutions was impossible, and so the only alternative was to mobilize the people. 'The people', in the eyes of the revolutionaries, had to extend far beyond the political nation: whereas it was defined by its Protestantism and its property, the revolutionaries sought to mobilize the mass of the population, which meant mobilizing Catholics, including the poor peasantry.

An early attempt to mobilize popular opinion using the French Revolution revealed the extent of the revolutionary vision. This Address from the National Assembly of France to the People of Ireland (August 1790) was a fake written by the Whigs of the Capital, a group of radicals active in Dublin city politics. The group's leadership - men such as James Napper Tandy (1739-1803) and John Chambers (1754-1837) - would subsequently be prominent in the United Irishmen, and as such it is a document that reveals much about the development of revolutionary ideology in Ireland. In its attacks on monarchy, aristocracy, and the clergy, in its vision of an Ireland free of sectarian divisions and a Europe of fraternal nations permanently at peace, it is unmistakably a product of the Radical Enlightenment.

The Address mounted a sustained attack on the nature of Ireland's relationship with Britain, on Ireland's constitution and politics, on aristocracy, on the power of the clergy, on the poverty of the people, and on what it described as an international counter-revolutionary conspiracy of despots to crush the Revolution - a campaign destined, it said, to be led by Britain. It portrayed a world where, by making governments truly representative of the people, a brighter future can be built where liberty will be enjoyed by all, where the people will be lifted out of poverty by the end of war, by the increase of peaceful commerce among nations, and by a halt being put to the exploitation of the labouring classes by monarchs, aristocrats, and clergy. Just as 
government could be a source of misery and war - an art used by kings to keep nations divided from one another - 'there is an art of philanthropy to restore and perfect the human race, when nations concur to say - such is our WILL'. 34

The belief in the perfectibility of the human race informed every aspect of the Address and its vision of a better future. In its emphasis on the improvement of conditions of this world, it reflected one of the factors that marked the Enlightenment out as a new phase in humanity's understanding of its place in the world. According to the Address, it was not just the spread of knowledge but the reform of political institutions that were the key to human progress. That meant confronting false political notions. In Ireland, that meant facing up to the reality of the constitution of 1782. The French, the Address said, had declared that any state that did not properly assure 'the rights of liberty, of property, of security, to all its citizens, without exception, and of resistance to oppression, has NO CONSTITUTION'. ${ }^{35}$ The message was clear. Despite the pretensions of Irish political culture that its constitution represented the epitome of Enlightened government, Ireland lacked a genuine constitution because its confessional state denied equal rights to 90 per cent of the population. Freedom as defined by those with a moderate conception of Enlightenment was a sham - France had proven that religion and politics should be kept separate. The terms in which the claim that Ireland lacked a constitution were made could have stemmed from a radical reading of Locke, and certainly during the 1790s Irish revolutionaries cited Locke to claim that they were acting according to established principles. However, it was also the case that Locke was used as convenient camouflage for the rejection of the entire political and social system. The rejection of the constitution marked the revolutionaries of the 1790s out from the radical reformers of previous decades. 
The three pillars of ancien régime Europe - 'a man dressed in lace' (the aristocracy), 'another man dressed in black' (the clergy), and 'another man dressed in scarlet' (the monarchy) - were denounced for robbing the people of the fruits of their labour, condemning them to live in hovels and to die for the selfish interests of others. The oppression of these three needed to be ended once and for all for humanity to flourish. This necessitated revolutionary change, 'regeneration'. 'Political abuses must be overturned completely and all at once, or not at all - A slow and partial reform always ends where it begun,.36 Thus the British constitutional tradition of slow and gradual reform, represented by moderate Enlightenment figures like Burke and embodied in Ireland by the likes of the Whig Henry Grattan, was dismissed as completely inadequate to meet the needs of the people and to guarantee their natural rights. Revolutionary change was the only possible solution. The radical interpretation of Enlightenment principles had led the author(s) to this conclusion.

This revolutionary message did not meet with much success in the Ireland of 1790 . How then did it soon gain a huge following? The revolutionaries benefited from changing circumstances. The hostility of the domestic political elite to the campaign to extend additional rights to Catholics radicalized Catholic opinion as Catholics were only granted the vote (but not the right to sit in parliament or hold office) in 1793 because London insisted that the members of the Irish parliament that enjoyed its patronage toe the line. The refusal to grant parliamentary reform pushed some people towards more radical solutions. The development of the French Revolution also helped radicalize opinion as the example of a modern democratic republic fighting counter-revolutionaries at home and abroad demonstrated what was possible, and made the prospect of French help for an Irish revolution likely. The demands of the war, especially the creation of a militia in 1793 that sparked massive resistance across the island, and its impact on 
the economy further polarized Irish politics. While such factors were of the utmost importance, so too were the efforts of the revolutionaries themselves, as they used every means at their disposal to achieve their goal 'to make every man a politician'. 37

Wolfe Tone was a key figure in helping create a climate where the revolutionary message met with success, through his various activities as a propagandist, an activist, an organizer, and ultimately as an unofficial diplomat negotiating with Lazare Carnot and the Directory. Like the other revolutionaries, Tone was convinced that the revolution of 1782 'was the most bungling, imperfect business that ever threw ridicule on a lofty epithet by assuming it unworthily', and that there was a need to reshape Ireland's government and society according to the principles of liberty and equality. ${ }^{38}$ His most important written work was An Argument on behalf of the Catholics of Ireland (August 1791), written in response to the failure to endorse equal rights for Catholics by the massive meeting in Belfast to celebrate the second anniversary of the French Revolution. It was not, the pamphlet declared, necessary to discuss whether the people had the right to reform the government, Paine having settled that question in Part I of Rights of Man. It was, however, necessary for Protestant reformers to put aside their suspicions of Catholics and embrace them as brothers. This was the only means of addressing Ireland's real problem, the fact that 'we have no National Government, in which we differ from England and all Europe'. 39 Ireland had a government that derived from another country, and her interests were sacrificed by the corrupt puppets of foreigners. 1782 had failed because those seeking their own freedom sought to keep the Catholics in slavery, a problem that still dogged the campaign for change. To those who doubted that Catholics could be trusted, Tone pointed to the fact that the Pope had been burnt in effigy in Paris, and claimed that Irish Catholics would ignore 'rusty and extinguished thunderbolts of the Vatican'. 40 At a time when freedom was spreading across 
Europe, all that was needed was that the people of Ireland 'once cry Reform and the Catholics, and Ireland is free, independent and happy'. 41

Tone's Argument, which made its case on the basis of natural rights and the example of France and America where religion had been separated from politics, was the most popular Irishauthored pamphlet of the 1790 s, and second in sales only to Paine's Rights of Man. ${ }^{42}$ To a large extent it achieved its purpose of convincing Presbyterian radicals to embrace equality for Catholics, and in its wake Tone was invited to help found the United Irishmen. It also earned him the job of secretary to the Catholic Committee when it decided to adopt a more militant approach. That he replaced Edmund Burke's son Richard symbolized how the failure of moderate politics reflecting moderate understandings of Enlightenment to meet popular demands pushed people towards revolutionary politics reflecting radical understandings of Enlightenment. Tone became the chief propagandist for the Committee, arguing amongst other things that in 'this enlightened period' it was time for bigotry to sink into oblivion. ${ }^{43}$ Tone was also one of the primary organizers of the Catholic Convention of December 1792, when delegates elected by universal manhood suffrage among Catholics demanded greater rights. ${ }^{44}$ At the same time, Tone was involved in an attempt with other United Irishmen to launch a Volunteer unit modelled explicitly on the French National Guard, with a similar uniform designed to be available cheaply to allow the poor of all denominations to participate. Tone's design for its emblem of an Irish harp without the Crown above it was an explicit statement of the unit's commitment to an independent Irish democratic republic. The government suppressed the Volunteers shortly after its foundation was announced.

Tone sought to propagate revolutionary politics through his writing and his actions. He had several opportunities to place his pen at the disposal of the Irish Whigs, whose patronage 
might have secured him a seat in the Irish parliament. However, he ultimately chose to stick to his principles: his political career ended with him dying in prison in Dublin following his capture aboard a French ship in 1798, having cut his own throat. The sources of his principles are somewhat unclear. Tone deliberately avoided citing other authors in his works, which were always written as propaganda pieces for specific purposes, rather than as philosophical reflections. Certainly he acknowledged Paine - a favoured author of the United Irishmen, who distributed both Rights of Man and Age of Reason gratis among the populace - as an important influence, and traces of his having read other Enlightenment figures like Locke and Hume are present in his work, but if he read figures like Spinoza, Diderot, or D'Holbach, he never made it obvious. 45

Nor did his fellow United Irishmen, who like him focused on practical issues and propaganda in their writings. The Northern Star carried extensive reports of speeches from the various French assemblies, as well as extracts from the works of Enlightened authors, including some radical philosophes such as comte de Volney, and works by Condorcet and Brissot were published in translation in Ireland. ${ }^{\mathbf{4 6}}$ There were certainly deists and probably atheists among the United Irish leadership, as the printing and distribution of Paine's Age of Reason suggests. It seems therefore highly likely that sections of the United Irishmen were influenced by radical philosophes. However, for others, like Tone's closest friend and fellow United Irish leader Thomas Russell (1767-1803), religion played a major role in shaping their politics. ${ }^{47}$ The Belfast United Irishmen also printed prophecies in the Northern Star and in pamphlet form that they believed would help them gain support among the populace, especially Dissenters who interpreted the French Revolution as a harbinger of the Millennium. ${ }^{48}$ Given the lack of a highly developed culture of philosophical debate within Ireland, the intended audience of United Irish 
publications, the range of religious opinions contained within the United Irishmen, the centrality of religious denomination to Irish life, and the general religiosity of Irish society, it is perhaps not surprising that while the political programme of Irish revolutionaries clearly represents the political ideas of Radical Enlightenment, debate about pantheism or one-substance metaphysics is noticeable by its absence. By the time Irish politics were being heavily influenced by ideas associated with Radical Enlightenment, it was in their mediated and practical political form.

Given Tone's centrality to the development of the Irish revolutionary programme, he offered a summary of its priorities when he summed up his own political approach in 1796:

To subvert the tyranny of our execrable government, to break the connexion with England, the never failing source of all our political evils, and to assert the independence of my country - these were my objects. To unite the whole people of Ireland, to abolish the memory of all past dissensions, and to substitute the common name of Irishman in place of the denominations of Protestant, Catholic and Dissenter - these were my means.

Put differently, Tone believed that the purpose of government was to protect and reflect natural rights and equality. He believed that the British connection and the native aristocracy who governed in tandem with it and profited from its patronage (or 'corruption' as Tone preferred to call it) had to be destroyed if the rights of the people of Ireland, both as individuals and as a nation, were to be respected. To achieve this, sectarianism had to be left behind and secular politics embraced. In both America and the Batavian Republic, Tone identified an aristocracy of money rather than birth, and he regarded it with the same contempt he did traditional aristocracy. His belief in equality therefore extended beyond religious equality to sympathy with those he termed 'that numerous and respectable class of the community, the men of no property'. 50 
was a republican democrat, and he and the United Irishmen as a whole placed themselves firmly in the camp of those internationally who were trying to bring a new era of Enlightenment, of liberty and equality as represented by the French Revolution. While they insisted on the rights of their nation, to reduce them to one link in a chain of Irish nationalists across the centuries is to miss something fundamental about their self-image and their politics, their internationalism, emblematic of the Radical Enlightenment.

\section{Conclusion}

The revolutionary ideology that emerged in Ireland in the last quarter of the eighteenth century aimed to establish a democratic, secular, and independent Irish republic that would take its place in a new world order shaped by the forces of Enlightenment and revolution, and usher in a new and better era for humanity. It foresaw government and social institutions reshaped according to the interests and desires of the people, and the removal of the burdens placed on them by the demands of kings, aristocrats, and priests. In this new world, liberty would be triumphant, poverty alleviated, and old hatreds resolved. This was in accordance with the political ideas associated with the Radical Enlightenment. There were other sources of motivation for revolutionaries in 1790s Ireland, including Millenarianism, radical Lockeanism, classical republicanism, social and economic grievances, and even in some cases a hope for Catholic revanche, but the ideology of the United Irishmen was unmistakably shaped by the most radical political ideas that sprang from the re-examination of human society and humanity's place in the world later called the Enlightenment. Although the example of the American Revolution had helped produce some shifts towards a revolutionary ideology, it was the example, principles, and 
impact of the French Revolution that created the conditions in which this ideology was fully developed. The structural problems of Irish society allowed this ideology to build a mass following. In a political culture that regarded itself as moderate and Enlightened, it was natural that those who wanted change would embrace the politics of the Radical Enlightenment. This involved abandoning any faith in the existing constitution and the ideas that shaped it. This difference can be illustrated in attitudes towards natural rights and rights within society. Historically regarded as two different things, this facilitated the religious discrimination on which Irish politics were built. The United Irishmen, like the French democratic revolutionaries, refused to accept this distinction. The world they wanted to create was a world shaped by the egalitarian political and social values of the most radical thinkers of the Enlightenment.

\section{Notes}

\section{Select bibliography}

\section{Berman, David, 'Enlightenment and Counter-Enlightenment in Irish philosophy', Archiv für}

Geschichte der Philosophie, 64 (1982): 148-65.

Berman, David, 'The Causation and Culmination of Irish Philosophy', Archiv für Geschichte der

Philosophie, 64 (1982): 257-79.

Berman, David and Patricia O'Riordan (eds.), The Irish Enlightenment and Counter-

Enlightenment (6 vols.) (Bristol: Thoemmes Press, 2002).

Brown, Michael, 'Was there an Irish Enlightenment?: The Case of the Anglicans', in Richard

Butterwick, Simon Davies and Gabriel Sánchez Espinosa (eds.), Peripheries of the

Enlightenment (Oxford: Voltaire Foundation, 2008), pp. 49-64. 
Brown, Michael, The Irish Enlightenment (Harvard: Harvard University Press, 2016).

Connolly, Sean J., Divided Kingdom: Ireland, 1630-1800 (Oxford: Oxford University Press, 2008).

Curtin, Nancy J., The United Irishmen: Popular Politics in Ulster and Dublin, 1797-1798 (Oxford: Oxford University Press, 1994).

Davies, Simon, 'The Northern Star and the Propagation of Enlightened Ideas', EighteenthCentury Ireland/Iris an dá chultúr, 5 (1990): 143-52.

Dickson, David, Dáire Keogh and Kevin Whelan (eds.), The United Irishmen: Republicanism, Radicalism and Rebellion (Dublin: Lilliput Press, 1993).

Elliott, Marianne, Partners in Revolution: The United Irishmen and France (New Haven: Yale University Press, 1982).

Elliott, Marianne, Wolfe Tone (Liverpool: Liverpool University Press, $2012^{2}$ [1989]).

Gargett, Graham and Geraldine Sheridan (eds.), Ireland and French Enlightenment, 1700-1800 (London: Macmillan, 1999).

Gillen, Ultán, 'Varieties of Enlightenment: The Enlightenment and Irish Political Culture in the Age of Revolutions', in Richard Butterwick, Simon Davies and Gabriel Sánchez Espinosa (eds.), Peripheries of the Enlightenment (Oxford: Voltaire Foundation, 2008), pp. $163-81$.

McBride, Ian, Scripture Politics: Ulster Presbyterians and Irish Radicalism in the Late Eighteenth Century (Oxford: Oxford University Press, 1998).

McBride, Ian, Eighteenth-Century Ireland: The Isle of Slaves (Dublin: Gill \& Macmillan, 2009). Moody, T.W., R.B. McDowell and C.J. Woods (eds.), The Writings of Theobald Wolfe Tone (3 vols.) (Oxford: Oxford University Press, 1998-2007). 
Morley, Vincent, Irish Opinion and the American Revolution, 1760-1783 (Cambridge: Cambridge University Press, 2002).

Small, Stephen, Political Thought in Ireland, 1776-1798: Republicanism, Patriotism and Radicalism (Oxford: Oxford University Press, 2002).

Smyth, Jim, The Men of No Property: Irish Radicals and Popular Politics in the Late Eighteenth Century (Dublin: Gill \& MacMillan, 1992).

Smyth, Jim, "Wolfe Tone's Library: The United Irishmen and "Enlightenment", EighteenthCentury Studies, 45 (2012): 423-35.

Whelan, Kevin, The Tree of Liberty: Radicalism, Catholicism and the Construction of Irish Identity, 1760-1830 (Cork: Cork University Press, 1996).

Northern Star, 1 June 1795, p. 2. Published in Belfast, this was the United Irish newspaper from January 1792 until its suppression by government in May 1797.

2 Catholics comprised about 80 per cent of the population and were completely excluded from political power until 1793, when they received the vote but not the right to sit in parliament. The Dissenters, about 10 per cent of the population overwhelmingly concentrated in Ulster, could sit in parliament but were barred from office. Both denominations also suffered other forms of religious discrimination due to the Penal Laws.

3 On Tone, see Marianne Elliott, Wolfe Tone (Liverpool, 2012 [1989]); T.W. Moody, R.B. McDowell and C.J. Woods (eds.), The Writings of Theobald Wolfe Tone (3 vols) (Oxford, 1998-2007). 
R.F. Foster, Modern Ireland, 1600-1972 (Harmondsworth, 1987), p. 280. On the United Irishmen, see Marianne Elliott, Partners in Revolution: The United Irishmen and France (New Haven, 1982); Nancy J. Curtin, The United Irishmen: Popular Politics in Ulster and Dublin, 1797-1798 (Oxford, 1994); Jim Smyth, The Men of No Property: Irish Radicals and Popular Politics in the Late Eighteenth Century (Dublin, 1992); Kevin Whelan, The Tree of Liberty: Radicalism, Catholicism and the Construction of Irish Identity, 1760-1830 (Cork, 1996); Stephen Small, Political Thought in Ireland, 17761798: Republicanism, Patriotism and Radicalism (Oxford, 2002); and Ian McBride, Eighteenth-Century Ireland: The Isle of Slaves (Dublin, 2009), pt. 4 [on the 1798 rebellion]. Thomas Pakenham, The Year of Liberty: The Great Irish Rebellion of 1798 (London, 1969) remains the key narrative, though the interpretation is now severely out of date.

Northern Star, 1 February 1792, pp. 2-3.

David Berman, 'Enlightenment and Counter-Enlightenment in Irish Philosophy', Archiv für Geschichte der Philosophie, 64 (1982): 148-65 and David Berman, 'The Causation and Culmination of Irish Philosophy', Archiv für Geschichte der Philosophie, 64 (1982): 257-79. Berman elaborated on his argument in the introduction to David Berman and Patricia O'Riordan (eds.), The Irish Enlightenment and Counter-Enlightenment (6 vols) (Bristol, 2002), vol. 1, pp. 1-15.

Simon Davies, 'The Northern Star and the Propagation of Enlightened Ideas', EighteenthCentury Ireland/Iris an dá chultúr, 5 (1990): 143-52.

For example, Elliott, Partners in Revolution, ch. 1; A.T.Q. Stewart, A Deeper Silence: The Hidden Origins of the United Irishmen (London, 1993); Peter Tiesch, 'Presbyterian 
Radicalism', in David Dickson, Dáire Keogh and Kevin Whelan (eds.), The United Irishmen: Republicanism, Radicalism and Rebellion (Dublin, 1993), pp. 33-48; Ian McBride, 'William Drennan and the Dissenting Tradition', in Dickson, Keogh and Whelan (eds.), The United Irishmen, pp. 49-61; Ian McBride, 'The School of Virtue: Francis Hutcheson, Irish Presbyterians and the Scottish Enlightenment', in Robert Eccleshall, D. George Boyce and Vincent Geoghegan (eds.), Political Thought in Ireland Since the Seventeenth Century (London, 1993), pp. 73-99; Curtin, United Irishmen, ch. 1; Ian McBride, Scripture Politics: Ulster Presbyterians and Irish Radicalism in the Late Eighteenth Century (Oxford, 1998); Whelan, The Tree of Liberty, especially pp. 59-96; and Jim Smyth, 'Wolfe Tone's Library: The United Irishmen and "Enlightenment"', Eighteenth-Century Studies, 45 (2012): 423-35. Unfortunately, this title is metaphorical since Tone's library has long been lost.

McBride, Isle of Slaves, ch. 2.

10 For example, Sean J. Connolly's Divided Kingdom: Ireland, 1630-1800 (Oxford, 2008) adds a question mark to its section entitled 'Improvement and Enlightenment?', pp. 372-5. Ulrich Im Hof has argued that the Royal Dublin Society provided a model followed on the Continent in his The Enlightenment (Oxford, 1994), pp. 123-5.

11 Ultán Gillen, 'Varieties of Enlightenment: The Enlightenment and Irish Political Culture in the Age of Revolutions', in Richard Butterwick, Simon Davies and Gabriel Sánchez Espinosa (eds.), Peripheries of the Enlightenment (Oxford, 2008), pp. 163-81. This collection contains two essays on Ireland, fitting the Irish Enlightenment into a comparative perspective. 
12 Faulkner's Dublin Journal, 29 March 1792, p. 3. Henry Grattan (1746-1820) was a leading Irish patriot and Whig, regarded as the greatest orator in the Irish parliament.

13 John Robertson, The Case for the Enlightenment: Scotland and Naples, 1680-1760 (Cambridge, 2005).

14 On Toland, see Justin Champion, Republican Learning: John Toland and the Crisis of Christian Culture, 1696-1722 (Manchester, 2003) and Michael Brown, A Political Biography of John Toland (London, 2011). See also Ian Leask, Chapter 7 in this volume. 15 Margaret C. Jacob, The Radical Enlightenment: Pantheists, Freemasons and Republicans (Lafayette, LA, 2006 [1981]), p. xi.

16 Jonathan I. Israel, Radical Enlightenment: Philosophy and the Making of Modernity, 16501750 (Oxford, 2001), p. 613.

17 Champion, Republican Learning, pp. 73, 77.

18 Jonathan I. Israel, Democratic Enlightenment: Philosophy, Revolution, and Human Rights, 1750-1790 (Oxford, 2011), p. 10.

19 Seamus Deane, 'The Great Nation and the Evil Empire', Field Day Review, 5 (2009): 20743, p. 240.

Smyth, 'Wolfe Tone's Library', p. 431.

21 Máire Kennedy and Geraldine Sheridan, 'The Trade in French Books in Eighteenth-Century Ireland', Graham Gargett and Geraldine Sheridan (eds.), Ireland and French Enlightenment, 1700-1800 (London, 1999), pp. 174-97.

22 For example, published in English in Dublin were Raynal's Histoire des deux Indes (1776), Volney's Vogage en Syrie et en Égypte (1788-93), and Diderot's La religieuse (1797). 
See also Davies, 'The Northern Star and the Propagation of Enlightened Ideas', and the essays in Gargett and Sheridan (eds.), Ireland and French Enlightenment.

23 Vincent Morley, Irish Opinion and the American Revolution, 1760-1783 (Cambridge, 2002), pp. $330-4$.

24 William Drennan, The Letters of Orellana, an Irish Helot (Dublin, 1785), pp. 5-6.

25 Drennan, The Letters of Orellana, pp. 7-10.

26 Drennan, The Letters of Orellana, p. 11.

27 Drennan, The Letters of Orellana, pp. 12-14.

28 Israel, Democratic Enlightenment, p. 12.

29 McBride, Scripture Politics, p. 91.

30 Two particularly striking examples of different sorts are from a member of parliament advocating liberty for Catholics, William Todd Jones, A Letter to the Electors of the Borough of Lisburn by One of their Representatives (Dublin, 1784) and a short poem sold in a chapbook that attacked monarchy, aristocracy, and clerical influence in politics, Ireland's Glory; Or, A Comparative View of Ireland in the Years 1776 and 1783 (Newry, $1783[?])$

31 Tone, Writings, vol. 2, p. 295.

32 Morning Post or Dublin Courant, 27 August 1789, p. 1.

33 Northern Star, 27 October 1792, p. 2 (reporting toasts drunk in celebration of French success by a company of Volunteers).

\footnotetext{
34 Address from the National Assembly of France to the People of Ireland (Dublin, 1790), p. 7. 35 Address from the National Assembly of France, p. 8.

36 Address from the National Assembly of France, p. 13.
} 
William James Mac Neven, Pieces of Irish History, Illustrative of the Condition of the Catholics of Ireland, of the Origin and Progress of the Political System of the United Irishmen; and of their Transactions with the Anglo-Irish Government (New York, 1807), p. 77.

38

Tone, Writings, vol. 1, p. 112.

39

Tone, Writings, vol. 1, p. 111.

Tone, Writings, vol. 1, p. 122.

41

Tone, Writings, vol. 1, p. 128.

42

Rights of Man had sold forty thousand copies in Ireland by November 1791. After Tone's work sold six thousand copies in a few months, ten thousand more were printed. David Dickson, 'Paine and Ireland', in Dickson, Keogh and Whelan (eds.), United Irishmen, p, 137; Elliott, Wolfe Tone, p. 123.

43 Tone, Writings, vol. 1, p. 305.

44

On the Catholic question, see Thomas Bartlett, The Fall and Rise of the Irish Nation: The Catholic Question, 1690-1830 (Dublin, 1992).

45

The United Irish songbook, Paddy's Resource, included several items praising Paine, including The Dictates of Reason, which called on the Irish people to 'attend to the dictates of Reason and Paine', and use 'the powers of our Reason enlighten'd and free' against oppression (Paddy's Resource (Belfast, 1795), p. 75). Tone's unpublished 'Reply to a pamphlet entitled The Protestant Interest in Ireland Ascertained' explicitly cited Locke and Hume against his opponent (Tone, Writings, vol. 1, pp. 174-5). 46 Condorcet's Outlines of an Historical View of the Progress of the Human Mind (Dublin, 1796) was published by Tone's printer, the United Irishman John Chambers. Brissot's 
New Travels in the United States of America and Letter To His Constituents, on the Situation in the National Convention were published in Dublin in 1792 and 1794 respectively. On Volney, see note 22. A broadsheet aimed at the lower orders also featured Volney (Smyth, Men of No Property, pp. 166-7).

On Russell, see James Quinn, Soul on Fire: A Life of Thomas Russell (Dublin, 2002). 48 For example, a prophecy dating from 1701 was printed at the Northern Star office (Robert Fleming, A Discourse on the Rise and Fall of AntiChrist; wherein the French Revolution and the Downfall of Monarchy in that Kingdom are distinctly pointed out [Belfast, 1795]). On the influence of Millenarianism in Presbyterian support for the French Revolution and the United Irishmen, see McBride, Scripture Politics, pp. 195-200. Tone, Writings, vol. 2, p. 301. Tone, Writings, vol. 2, p. 107. 